\title{
Influence of juvenile and mature wood on anatomical and chemical properties of early and late wood from Chinese fir plantation
}

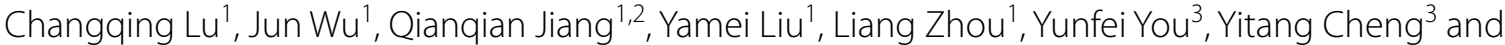 \\ Shengquan Liu ${ }^{1 *}$
}

\begin{abstract}
The proportion of juvenile wood affects the utilization of wood seriously, and the transition year of juvenile wood (JW) and mature wood (MW) plays a decisive role in the rotation and the modification of wood. To find out the demarcation of JW and MW, the tracheid length (TL) and microfibril angle (MFA) of early wood (EW) and late wood (LW) from four Chinese fir clones were measured by optical microscopy and X-ray diffraction. Then the data were analyzed by the k-means clustering method. The correlation and the differences among wood properties between JW and MW were compared. Results indicated that the LW showed better properties than that of EW, but the anatomical differences between EW and LW did not influence the demarcation of JW and MW. The cluster analysis of TL and MFA showed that the transition year was in the 16th year and the transition zone of EW and LW was different among clones. The MW has longer and wider tracheid, thicker cell walls, and smaller MFA. In terms of chemistry, MW had a higher content of holocellulose, a-cellulose, less content of extract, but no significant difference in lignin content compared with JW. The stabilization of chemical components was earlier than that of the anatomic properties. Correlation analysis showed that there were strong correlations between the chemical composition and anatomical characteristics in JW and MW. In general, compared with chemical components, anatomical indicators were more suitable for JW and MW demarcation. The differences and correlations between JW and MW properties provide a theoretical basis for wood rotation and planting.
\end{abstract}

Keywords: Cunninghamia lanceolata, Type of wood, Transition, Anatomical characteristics, Chemical composition

\section{Introduction}

The traditional wood production and the collection of wood derivatives products based on the logging of natural forests have led to the gradual exhaustion of natural resources, but also lead to soil erosion, drought, flood, and biological extinction. The fundamental solution to this problem is to adopt oriented cultivation, wood efficient utilization technology, and establish a high-quality

*Correspondence: liusq@ahau.edu.cn

1 School of Forestry and Landscape Architecture, Key Lab of State Forest and Grassland Administration on "Wood Quality Improvement and High Efficient Utilization", Anhui Agricultural University, Hefei 230036, China Full list of author information is available at the end of the article industrial wood plantation. Planted forests are increasing rapidly in the world to alleviate deforestation and natural forest degradation, while providing a variety of goods and services [1]. Forest plantations have been supplying up to $33 \%$ of the total industrial roundwood in the world and are expected to reach $50 \%$ of the global industrial roundwood production by 2040 [2]. China has the largest area of plantation reserves in the world [3]. At the same time, softwood is one of the most important renewable resources on earth. It is mainly used as a material in the structural components of wooden structures [4]. Chinese fir (Cunninghamia lanceolata [Lamb.] Hook.), the most important conifer species for timber production and has wide geographic distribution in southern China,
Springer Open
(C) The Author(s) 2021. Open Access This article is licensed under a Creative Commons Attribution 4.0 International License, which permits use, sharing, adaptation, distribution and reproduction in any medium or format, as long as you give appropriate credit to the original author(s) and the source, provide a link to the Creative Commons licence, and indicate if changes were made. The images or other third party material in this article are included in the article's Creative Commons licence, unless indicated otherwise in a credit line to the material. If material is not included in the article's Creative Commons licence and your intended use is not permitted by statutory regulation or exceeds the permitted use, you will need to obtain permission directly from the copyright holder. To view a copy of this licence, visit http://creativecommons.org/licenses/by/4.0/. 
accounting for $20-30 \%$ of the total commercial timber production which has important commercial significance for timber and pulp industry [5-8]. Chinese fir is a subtropical tree species, which is planted well and utilized widely in practice in south area of China. KAI3, DABA8, KAI13 and KAI24 are four groups of Chinese fir clones selected by the Kaihua Country Forest Farm, which have excellent growth conditions. We studied wood properties for rational processing and efficient utilization. At the same time, our research groups have studied Chinese fir mechanical properties and their correlation with microstructures [9], but the influence of juvenile and mature wood on anatomical and chemical properties of early and late wood has not been studied yet. Therefore, it is of great significance to study the wood properties of Chinese fir plantation. The quality of wood is determined by the properties of JW (juvenile wood) and MW (mature wood), the utilization of wood is closely related to the proportion of these two parts [10]. For example, a high JW proportion involves a reduced lumber strength, warping problems during the drying process and a reduction of yields in pulp production [11]. Plantation trees are typically harvested after only 30 years and this means that approximately half of the timber produced originates from the juvenile part of the stem [12]. Wood located near the pith is commonly referred to as juvenile wood, and wood found further from the pith as mature wood [13]. Analyzing the radial variation of wood anatomical properties within stems can determine the boundary between the juvenile and mature wood [14-16]. Only by understanding the anatomical structure of wood can it be possible to understand why specific wood characteristics are formed and how it affects the way wood is used [17]. Darmawan discussed a transition age between juvenile and mature wood in order to infer an age of harvestability [18]. Fiber length and microfibril angle are the anatomical traits that determine wood quality [19]. Other properties such as ring area and latewood percentage also can define the extent of the core wood zone [13]. Compared to MW, JW has different properties, such as lower wood density, shorter fiber length, higher lignin content, and higher compression wood content $[20,21]$. Due to the strengthening of forestry practices and the promotion of more cost-effective production of raw materials, the increase in the proportion of JW in artificial forest resources is inevitable [13]. Methods that had received much attention to defining juvenile/mature wood are based on segmented regression analysis, piecewise regression model and k-means algorithm cluster analysis [22-28]. Modulus of elasticity/shear modulus also can be chosen as the index for determining the juvenile/mature wood boundary [29]. Studies to determine the chemical composition of juvenile and mature wood have revealed significant differences in the content of these components [30]. Chemical composition varies among and within tree species and also depend on the age and part of a tree [31]. The different species of wood and even its different areas are characterized by many physical and chemical features such as the shape of the tracheid, and the proportion of its chemical components [32].

In this paper, we found the demarcation of JW and MW of Chinese fir plantations by radial variation of TL (tracheid length) and MFA (microfibril angle) from EW (early wood) and LW (late wood), the less dense wood is named "early wood" or "spring wood", outer regions of growth rings are denser and correspond to the wood formed in summer or autumn, also named "late wood" [32], and then the anatomical characteristics and chemical components differences between JW and MW were compared. The results provide a theoretical basis for the directional cultivation and improvement of Chinese fir.

\section{Material and methods \\ Sample collection}

The four 20-year-old Chinese fir clones (KAI3, KAI13, DABA8 and F24) were collected from a forest farm in Kaihua County, Zhejiang Province. Kaihua $\left(118^{\circ} 01^{\prime}\right.$ east longitude, $28^{\circ} 54^{\prime}$ north latitude) features subtropical monsoon climate with an average temperature of $16.4{ }^{\circ} \mathrm{C}$, 1712.5-h sunshine, annual average rainfall of $1814 \mathrm{~mm}$ and 252-day frost-free period. 5 plants were prepared for each clone, a total of 20 plants. The basic information of experimental materials is shown in Table 1.

\section{Sample preparation}

A 70-mm-thick disc was cut from the trunk height of $1.3 \mathrm{~m}$ and cut the wood strips with a width of $1.5 \mathrm{~cm}$ outwards along the pith, and then cut the wood strips into small wooden blocks of $10 \mathrm{~mm}(\mathrm{R}) \times 10 \mathrm{~mm}(\mathrm{~T}) \times 15 \mathrm{~mm}(\mathrm{~L})$ according to different annual rings for the preparation of experimental specimens for anatomical characteristics (Fig. 1a). Samples were taken from the pith to the bark year by year according to the tree rings. Each year was divided into two parts: early and late wood; A disc with a certain thickness was cut at the height of $1.3 \mathrm{~m}$ for chemical components test, the disc was sawn into seven parts according to part A

Table 1 Details of four clones

\begin{tabular}{llll}
\hline Clones & Age (year) & Height $(\mathbf{m})$ & DBH $(\mathbf{c m})$ \\
\hline KAl3 & 20 & 18.0 & 17.8 \\
KAl13 & 20 & 17.1 & 17.0 \\
F24 & 20 & 22.3 & 19.9 \\
DABA8 & 20 & 19.0 & 17.5 \\
\hline
\end{tabular}




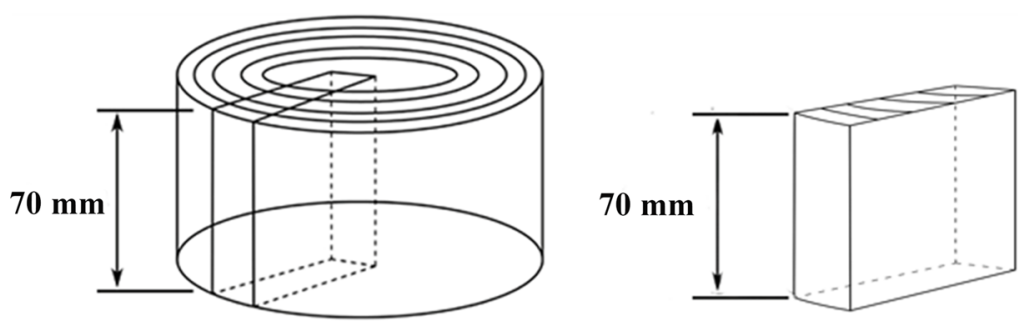

$\mathbf{a}$
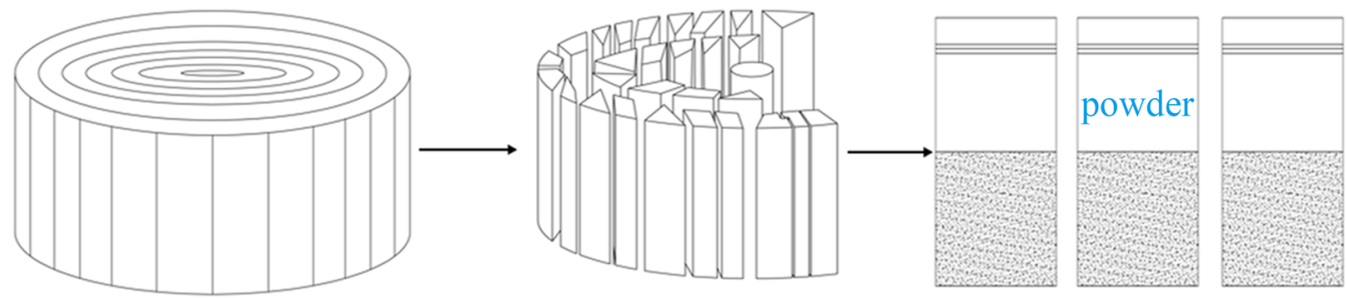

b

Fig. 1 Schematic diagram of wood sample preparation. a Sample preparation for anatomical properties; b sample preparation for chemical components

(1-4 years), part B (5-6 years), part C (7-8 years), part D (9-10 years), part $\mathrm{E}$ (11-13 years), part $\mathrm{F}$ (14-15 years), part G (16-20 years). After the raw material is crushed, 40-60 mesh samples were taken, and the chemical components were tested after water balance (Fig. 1b).

\section{The test method of wood anatomical properties}

For anatomical characterization, In accordance with the national standard, GB/T10336-2002 [33], wood macerations were conducted using glacial acetic acid and $30 \%$ hydrogen peroxide (1:1 ratio) at $80{ }^{\circ} \mathrm{C}$ for 4 h. 50 measurements were taken for the TL of both EW and LW. The samples were sliced by Leica RM2265 (Wetzlar, Germany), and the cross-section images with a ruler were taken by KEYENCE VHX-600E. The data were collected by ImageJ software. The thin slices of microfibril angle samples of each Chinese fir clone were determined by an $\mathrm{X}$-ray diffractometer (XD-3). The average MFA of each wood sample of Chinese fir clones was calculated by the $0.6 \mathrm{~T}$ method.

\section{The test method of wood chemical components}

The determination method mainly refers to the current national standards and other common methods, including GB/T 36055-2018 [34], GB/T 35816-2018 [35], GB/T 35818-2018 [36], GB/T 744-2004 [37]. The chemical composition content is based on the absolute dry wood, and the values were the average value of 5 samples in the group, with 3-5 parallel samples in each group.

\section{The method of k-means analysis}

$k$-means clustering represents one of the most popular clustering algorithms, which groups the unlabeled dataset into different clusters. With reference to Alboukadel Kassambara's suggestion, in this article we adopted the hierarchical k-means clustering method by Rstudio software. The algorithm is summarized as follows: (1) compute hierarchical clustering and cut the tree into k-clusters; (2) compute the center of each cluster; (3) compute k-means by using the set of cluster centers as the initial cluster centers. The code is available on DATANOVIA in the following repository: https://www.datan ovia.com/en/lessons/hierarchical-k-means-clusteringoptimize-clusters/.

\section{Results and discussion}

\section{Variation in tracheid length from pith to bark}

As shown in Table 2, the TL of LW was slightly longer than that of EW. In the study of radial variation in anatomical features, if the mean of data is skewed distribution, then it cannot describe the overall sample situation, if there is a large value of outliers, the average may be invalid. When the value of outliers is very high, a large amount of valuable data is also lost with truncated means. Therefore, this paper uses box plots to describe the data distribution of Chinese fir TL and MFA from the pith to the bark, to better observe the inflection point of the curve change. As shown in Fig. 2, the TL of Chinese fir increased rapidly at first 
Table 2 Tracheid length of early wood and late wood from four clones

\begin{tabular}{lll}
\hline Clone & Early wood $(\boldsymbol{\mu m})$ & Late $\operatorname{wood}(\boldsymbol{\mu m})$ \\
\hline KAl3 & $3234.93 \pm 634.26^{\mathrm{a}}$ & $3262.55 \pm 591.84^{\mathrm{a}}$ \\
DABA8 & $2662.04 \pm 829.97^{\mathrm{b}}$ & $2717.80 \pm 853.31^{\mathrm{b}}$ \\
KAl13 & $3037.65 \pm 686.83^{\mathrm{C}}$ & $3045.84 \pm 635.96^{\mathrm{c}}$ \\
F24 & $2865.94 \pm 649.08^{\mathrm{d}}$ & $2898.65 \pm 558.42^{\mathrm{d}}$ \\
F & 525.79 & 489.21 \\
Sig & 0.000 & 0.000 \\
\hline
\end{tabular}

Statistical differences between clones were denoted using lowercase letters, with different letters corresponding to significant differences $(p<0.05)$

and then slowly with the increase of growing years. The TL of LW is longer than that of EW, and the range is greater as well. The TL value from biggest to smallest was KAI3, KAI13, F24, DABA8. Among the four clones, the TL was an extremely significant difference between EW and LW.

The TL changes from the pith to the bark, curves have the similar tendency of a first rapidly increase, and then slowly, finally get stable with growth age. The blue dotted line marks the inflection point of rapid increase curve to slow increase curve and the slow increase curve to the stable line. In the EW part, the inflection points of the TL growth curves of the four groups of clones were 6th and 16th (Fig. 2a), 10th and 16th (Fig. 2c), 7th and 16th (Fig. 2e), 7th and 16th (Fig. 2g), respectively; In the LW part, the inflection points of the TL growth curves of the four groups of clones were 8th and 15th (Fig. 2b), 8th and 16th (Fig. 2d), 9th and 16th (Fig. 2f), 6th and 16th (Fig. 2h), respectively. In the first 6-8 years, the length of EW and LW tracheid increased rapidly, and the area of slow increase curve of EW tracheid was generally bigger than that of LW (e.g., KAI3, KAI13), there were also clones that get smaller than that of LW (e.g., DABA8), or no significant difference between EW and LW (e.g., F24). In general, the TL tends to stabilize around 16 years. The regression equation of TL $(y=a-b * \ln (x+c)$ can be determined by nonlinear fitting, in which $R^{2}$ is greater than 0.97 (Table 3).

The radial variation of TL of LW is accorded with logarithmic function. Although there were significant differences in TL among clones, the pattern of tracheid growth and the angle of microfibril in early and late clones were consistent with the annual rings and were stable in about 16 years. This tendency is a characteristic of JW formation in the tree's early years [38]. Although there were significant differences in $\mathrm{TL}$ among the four groups, the TL tended to be stable in the 16th year. Even if the inflection point of wood tracheid growth was about the 16th year, the transition zone was different among clones, which indicated that there were some inaccuracies in the determination of the wood transition area.

\section{Variation in microfibril angle from the pith to bark}

As shown in Table 4, the MFA of KAI3 EW and LW was the smallest. With the growth of tree age, except for LW of KAI3, there was no significant difference in MFA of EW and LW among different clones. The MFA of LW is smaller than that of EW, and the variation range of MFA of EW is larger than that of LW. Among them, the MFA of EW and LW from smallest to largest is KAI3, KAI13, F24 and DABA8. As shown in Fig. 3, the MFA of different clones had the same trend, and the fluctuation range of EW was significantly greater than that of LW. In the EW part, the MFA box of KAI3 (Fig. 3a), DABA8 (Fig. 3c), and F24 (Fig. 3g) dropped to the lowest point at 13-yearold, and KAI13 (Fig. 3e) at 12; In the LW part, the lowest points of each clone were: age 12 of KAI3 (Fig. 3b); 14 of DABA8 (Fig. 3d); 13 of KAI13 (Fig. 3f); 13 of F24 (Fig. 3h). The difference of clones had no significant effect on MFA. MFA of EW and LW showed a trend of first decreasing and then stabilizing, which consistent to Mario Vega's research results [39]. MFA declined to its lowest value around year 13 and then remained relatively stable with little fluctuation. Compared with tracheid length, MFA has lower transition ring, which was consistent with Darmawan's research results, confirmed that the determination of transition ring was dependent on the trait considered [18].

\section{Demarcation of juvenile and mature wood}

The hierarchical k-means algorithm was used for cluster analysis of Chinese fir MFA and TL and the $k$ value was set as number 4 . The clustering diagram of four sets of clones in different years was obtained as shown in Fig. 4. According to the diagram, the cluster analysis results of TL and MFA of EW and LW showed that they were divided into four parts: blue, yellow, green and red, corresponding to color labels $1,2,3$ and 4. In EW part, tree ages were divided into 3th-5th, 6th-9th, 10th-15th, 16th-20th (Fig. 4a) four categories; In LW part, tree ages were divided into three categories, 5th-8th, 9th-14th and 15th-20th (Fig. 4b), among which the blue part was not getting reasonably clustered.

Understanding the transition between JW and MW is an important first step in understanding wood quality and the modeling of fiber attributes [18]. According to the radial variation of TL and MFA, the inflection points of curves were located, which was subjective. Therefore, we use statistical classification ( $\mathrm{k}$-means clustering) to analyze TL and MFA. The demarcation of juvenile and 

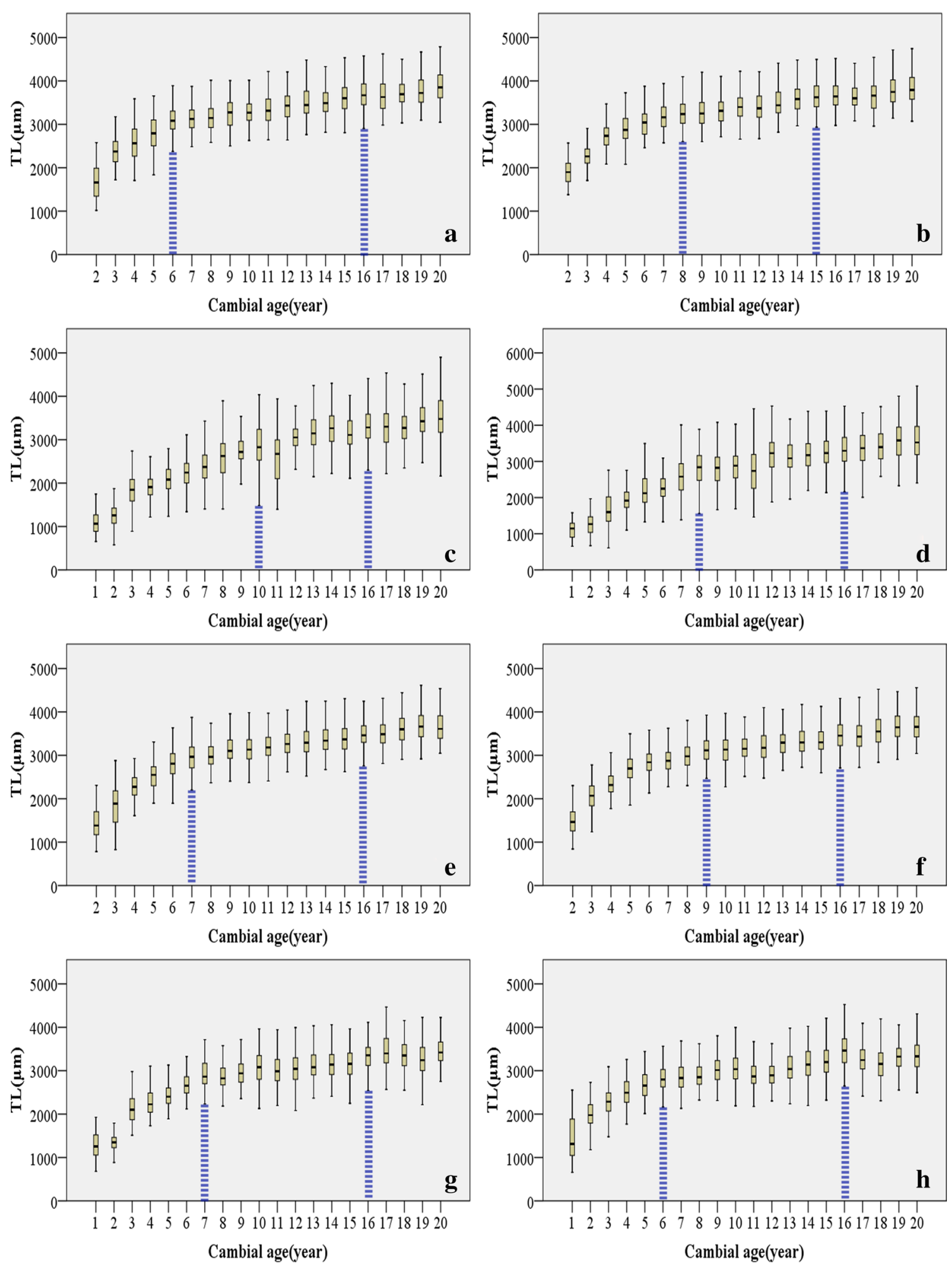

Fig. 2 The radial variation of tracheid length versus cambial age of Chinese fir. a TL of KAI3 EW; b TL of KAI3 LW; c TL of DABA8 EW; $\mathbf{d} T L$ of DABA8 LW; e TL of KAl13 EW; f TL of KAI13 LW; $\mathbf{g}$ TL of F24 EW; $\mathbf{h}$ TL of F24 LW 
Table 3 Regression equation of tracheid length

\begin{tabular}{llllll}
\hline Position & Equation & \multicolumn{4}{l}{$\boldsymbol{y}=\boldsymbol{a}-\boldsymbol{b}^{*} \ln (\boldsymbol{x}+\boldsymbol{c})$} \\
\cline { 3 - 6 } & Plot & KAI3 & DABA8 & KAl13 & F24 \\
\hline Early wood & $\mathrm{a}$ & 2101.16 & -147.34 & 1634.38 & 1421.56 \\
& $\mathrm{~b}$ & -577.88 & -1193.40 & -700.51 & -684.92 \\
& $\mathrm{c}$ & -1.52 & 1.67 & -1.30 & -0.28 \\
& $R^{2}$ & 0.99 & 0.98 & 0.99 & 0.97 \\
Late wood & $\mathrm{a}$ & 2173.88 & -58.61 & 1842.55 & 1914.96 \\
& $\mathrm{~b}$ & -550.32 & -1196.50 & -611.24 & -487.35 \\
& $\mathrm{c}$ & -1.4146 & 1.4183 & -1.4405 & -0.6470 \\
& $R^{2}$ & 0.99 & 0.98 & 0.99 & 0.97 \\
\hline
\end{tabular}

Table 4 Microfibril angle of early wood and late wood among clones

\begin{tabular}{lll}
\hline Clone & Early wood $\left(^{\circ}\right)$ & Late wood $\left(^{\circ}\right)$ \\
\hline KAl3 & $13.41 \pm 4.81^{\mathrm{a}}$ & $12.28 \pm 2.43^{\mathrm{b}}$ \\
DABA8 & $14.89 \pm 3.42^{\mathrm{a}}$ & $14.32 \pm 2.93^{\mathrm{a}}$ \\
KAl13 & $14.49 \pm 3.97^{\mathrm{a}}$ & $14.08 \pm 3.37^{\mathrm{a}}$ \\
F24 & $14.46 \pm 3.45^{\mathrm{a}}$ & $13.42 \pm 3.01^{\mathrm{ab}}$ \\
F & 2.13 & 7.83 \\
Sig & 0.100 & 0.000 \\
\hline
\end{tabular}

Statistical differences between clones were denoted using lowercase letters, with different letters corresponding to significant differences $(p<0.05)$

mature wood during the growth of trees was obtained by clustering the TL and MFA. It can be seen that the two groups of indicators did not get reasonable clustering results in 3-8 years (Fig. 4). The reason may be that the change of wood properties at the initial stage of tree growth is too changeable, which has a great impact on the clustering results. This is similar to the conclusion of Zhang who used SVM to analyze the mature and juvenile boundary of the Pinus banksiana plantation [40]. Therefore, the first 8 years of part were classified as JW part.

The clustering results showed that the EW reached maturity at the 16th year (Fig. 4a), while the LW reached maturity at the 15 th year (Fig. $4 \mathrm{~b}$ ). The results were consistent with the inflection points above. This is slightly different from the results of Jian L's study on the demarcation of Chinese fir plantation [41], which may be caused by the differences in tree planting area. The variation of MFA indicating that the maturity year of MFA was earlier than that of TL. Therefore, determining the transition year by MFA was not accurate.

\section{Differences of anatomical characteristics between juvenile wood and mature wood}

The average value of TL was $3515.98 \mu \mathrm{m}$ for MW and $2772.28 \mu \mathrm{m}$ for JW. TD of MW was $30.44 \mu \mathrm{m}$, and that of
JW was $28.13 \mu \mathrm{m}$. The DWT (double cell wall thickness) of MW was $7.13 \mu \mathrm{m}$, and that of JW was $6.81 \mu \mathrm{m}$. MFA of MW was $13.11^{\circ}$, and that of JW was $14.20^{\circ}$ (Table 5). TL, TD and DWT of MW were higher than those of JW, and MFA was lower than that of JW, and there were significant differences between JW and MW anatomical indexes. The values of TL, TD and DWT of clone KAI3 were the largest and MFA was the smallest among the four groups.

The lower strength of JW in most of the properties examined may be attributed to anatomical and chemical properties [42]. JW has important wood quality attributes because, depending on the species, it can have a shorter tracheid, larger microfibril angle [43]. MFA, which is defined as the angle of the cellulose microfibrils of the S2 layer of the secondary cell wall relative to the long axis of the cell [44]. MFA has a great influence on mechanical properties, stiffness and tensile strength [45-47]. The average microfibril angle in MW lies between 5 and $20^{\circ}$ to the fiber axis, but much larger angles are found in the JW of conifers [48]. The difference in the mean MFA values between early and late tracheid increases with increasing cambial age of the annual rings [49], it may explain why the MFA was not as stable as TL in mature wood. MW has longer tracheid, thicker cell wall and smaller MFA, which makes mature wood better than JW in wood utilization [50].

\section{Differences of chemical composition between juvenile wood and mature wood}

The content of lignin in MW was $33.34 \%, 33.22 \%$ in JW, $49.25 \%$ in $\alpha$-cellulose and $46.41 \%$ in JW, $73.58 \%$ in holocellulose and $72.57 \%$ in JW, $1.28 \%$ in extractive of MW and $2.08 \%$ in JW (Table 6). Wood was divided into seven parts along the radial direction, and part $G$ was the MW part. The contents of lignin, holocellulose and $\alpha$-cellulose in MW were higher than those in JW, which consistent with Funda research result [31]. Along the direction from pith to bark, the content of lignin increased slightly at site $G$, there was no significant difference among the sites, but the content of $\alpha$-cellulose increased gradually, and there was no significant difference between site $G$ and site $E$. The content of holocellulose had no significant difference at A-D, there was no significant difference in the content of holocellulose in part $\mathrm{E}$ and part $\mathrm{G}$. There was no significant difference in the content of extract in A-C, but a significant decrease in part $\mathrm{D}$. There was no significant difference in extract content between part $\mathrm{E}$ and part G (Fig. 5). In addition to the extractive content, the cellulose content and lignin content of MW were higher than that of JW. There was little difference in chemical composition between different clones, 

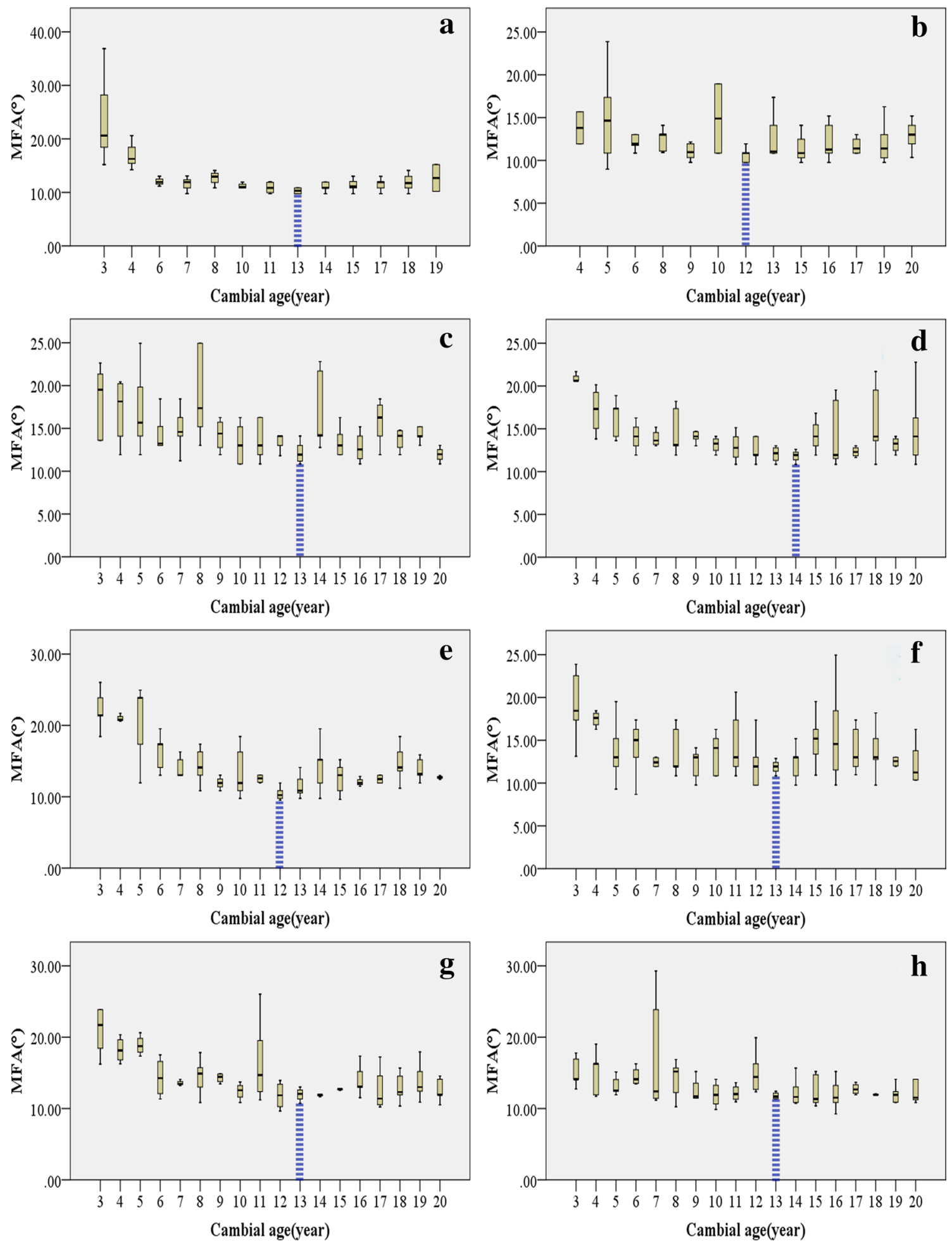

Fig. 3 The radial variation of microfibril angle versus cambial age of Chinese fir. a MFA of KAI3 early wood; $\mathbf{b}$ MFA of KAI3 late wood; $\mathbf{c}$ MFA of DABA8 EW; $\mathbf{d}$ MFA of DABA8 LW; $\mathbf{e}$ MFA of KAl13 EW; $\mathbf{f}$ MFA of KAl13 LW; $\mathbf{g}$ MFA of F24 EW; $\mathbf{h}$ MFA of F24 LW 
Table 5 Differences of anatomical characteristics between juvenile wood and mature wood

\begin{tabular}{|c|c|c|c|c|c|c|c|c|}
\hline \multirow[t]{2}{*}{ Clone } & \multicolumn{2}{|l|}{$\mathrm{TL}(\mu \mathrm{m})$} & \multicolumn{2}{|l|}{$\mathrm{TD}(\mu \mathrm{m})$} & \multicolumn{2}{|l|}{$\mathrm{DWT}(\mu \mathrm{m})$} & \multicolumn{2}{|l|}{ MFA $\left(^{\circ}\right)$} \\
\hline & J & $M$ & J & M & J & $M$ & J & $M$ \\
\hline KAI3 & $3075.93 \pm 598.38$ & $3725.28 \pm 345.94$ & $29.09 \pm 5.96$ & $32.02 \pm 6.49$ & $7.14 \pm 2.23$ & $7.41 \pm 2.37$ & $13.12 \pm 4.32$ & $12.06 \pm 1.75$ \\
\hline DABA8 & $2440.58 \pm 794.28$ & $3414.56 \pm 477.92$ & $27.93 \pm 4.60$ & $30.37 \pm 4.17$ & $6.40 \pm 2.26$ & $6.61 \pm 2.26$ & $14.82 \pm 3.29$ & $14.08 \pm 2.90$ \\
\hline KAl13 & $2848.20 \pm 640.50$ & $3582.85 \pm 343.98$ & $27.10 \pm 6.17$ & $29.14 \pm 5.63$ & $6.66 \pm 2.24$ & $7.04 \pm 2.85$ & $14.48 \pm 3.92$ & $13.53 \pm 2.82$ \\
\hline F24 & $2724.40 \pm 590.56$ & $3341.22 \pm 367.74$ & $28.38 \pm 6.15$ & $30.21 \pm 4.74$ & $7.02 \pm 2.61$ & $7.45 \pm 2.60$ & $14.36 \pm 3.57$ & $12.75 \pm 1.96$ \\
\hline Average & 2772.28 & 3515.98 & 28.13 & 30.44 & 6.81 & 7.13 & 14.20 & 13.11 \\
\hline
\end{tabular}

$T L$ tracheid length, $T D$ tracheid diameter, DWT double cell wall thickness, MFA microfibril angle, J juvenile wood, $M$ mature wood

Table 6 Differences of chemical composition between juvenile wood and mature wood

\begin{tabular}{|c|c|c|c|c|c|c|c|c|}
\hline \multirow[t]{2}{*}{ Clone } & \multicolumn{2}{|l|}{ Lignin (\%) } & \multicolumn{2}{|c|}{ a-Cellulose (\%) } & \multicolumn{2}{|c|}{ Holocellulose (\%) } & \multicolumn{2}{|l|}{ Extract (\%) } \\
\hline & J & $M$ & J & $M$ & J & $M$ & $J$ & $M$ \\
\hline KAl3 & $33.72 \pm 1.63$ & $33.95 \pm 1.60$ & $45.78 \pm 3.15$ & $49.03 \pm 0.97$ & $72.24 \pm 2.36$ & $73.10 \pm 1.92$ & $2.32 \pm 1.44$ & $1.34 \pm 0.54$ \\
\hline DABA8 & $32.96 \pm 1.34$ & $33.81 \pm 1.32$ & $47.27 \pm 2.50$ & $48.20 \pm 3.04$ & $72.84 \pm 1.77$ & $73.08 \pm 1.45$ & $1.95 \pm 0.98$ & $0.91 \pm 0.20$ \\
\hline KAl13 & $32.77 \pm 1.35$ & $31.95 \pm 0.41$ & $47.40 \pm 2.68$ & $51.56 \pm 0.96$ & $73.32 \pm 1.75$ & $74.90 \pm 2.63$ & $1.96 \pm 1.11$ & $1.36 \pm 0.81$ \\
\hline F24 & $33.43 \pm 1.27$ & $33.66 \pm 1.73$ & $45.21 \pm 2.20$ & $48.19 \pm 1.86$ & $71.89 \pm 1.76$ & $73.25 \pm 1.94$ & $2.08 \pm 0.81$ & $1.51 \pm 0.62$ \\
\hline Average & 33.22 & 33.34 & 46.41 & 49.25 & 72.57 & 73.58 & 2.08 & 1.28 \\
\hline
\end{tabular}

$J$ juvenile wood, $M$ mature wood
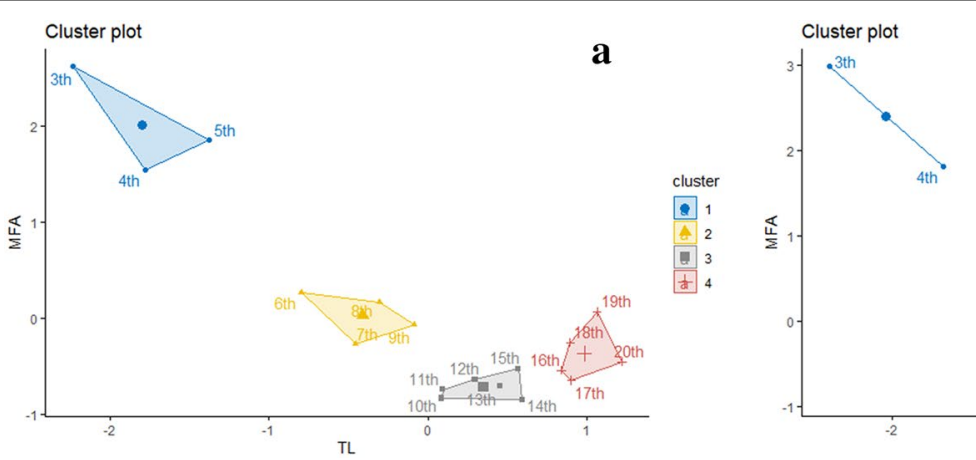

b

Fig. 4 k-means clustering analyses of MFA and TL. a Clustering plot of early wood; $\mathbf{b}$ clustering plot of late wood. Number 1-4 represent four different cluster groups

which may be due to the same growing environment and tree species $[31,51]$. The same lignin content may make the gap of mechanical strength between JW and MW narrowed.

There was no significant change of lignin in different parts along the radial direction, indicating that there was no significant difference in lignin content between JW and MW. There was no significant difference between extract, holocellulose and $\alpha$-cellulose in part E compared with part G (mature wood part), indicating that the chemical components in part E (1113 years) had reached the mature level [52].

\section{Correlation of wood anatomical properties and chemical} composition between juvenile and mature wood

For JW (Fig. 6a), the TL and TD were positively correlated with the extractive content, while for MW (Fig. 6b), they were negatively correlated; For JW, the DWT was negatively correlated with $\alpha$-cellulose $(R=-0.617)$, and for MW, it was positively correlated $(R=0.599)$; For JW, holocellulose was negatively correlated with $\alpha$-cellulose, but for MW, they were positively correlated $(R=0.535)$; The double wall thickness of JW was significantly positively correlated with the extract $(R=0.422)$, while there was no significant relationship in MW. That can be 



Fig. 5 Radial variation of chemical composition. The same letters on the bars were insignificant at the $5 \%$ significance level between the A-G using Tukey HSD tests

\section{Correlation Heatmap of juvenile wood}

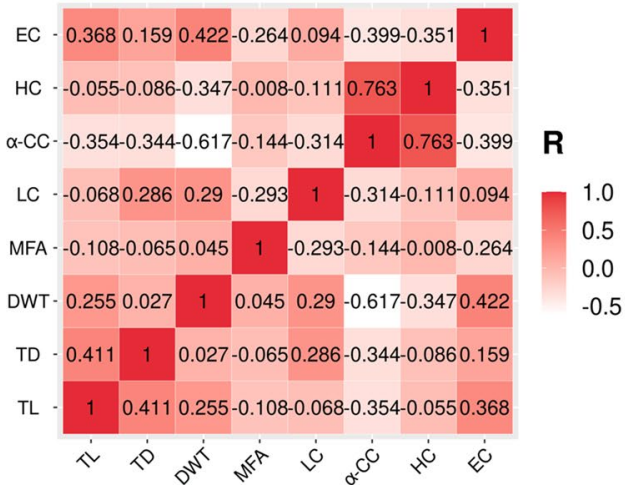

\section{Correlation Heatmap of mature wood}



Fig. 6 Correlation heatmap of wood properties. TL tracheid length, TD tracheid diameter, DWT double cell wall thickness, MFA microfibril angle, LC lignin content, $a$-CC a-cellulose content, $H C$ holocellulose content, EC extractive content

explained by the existence of heartwood. Heart wood accumulates a significant number of secondary metabolites (woody known as extractives) [53, 54].
The correlation heatmap was analyzed to provide a theoretical basis for the comprehensive improvement of wood properties. Many scholars have studied the correlation between wood properties, Such as the correlation 
coefficients between physical and chemical properties and correlation of wood anatomical properties $[16,55]$.

\section{Conclusion}

TL and MFA are two important anatomical indexes for the demarcation of JW and MW; the wood properties of coniferous wood are significantly different between EW and LW. Although LW properties were better than EW, the radial variation trends of different clones in the same area were basically the same, so there was no need to study separately. Through the study of the anatomical characteristics, it can be concluded that the transition year of Chinese fir was the 16th year. Cluster analysis is an appropriate method for the classification of wood properties. Compared with complex regression curves and subjective visual observations, the results were more scientific, reasonable and reliable. However, in chemical composition, the differences between the two types of wood were less than anatomical characteristics, and the stable time of chemical composition content was earlier than anatomical characteristics, so it was not appropriate to define the transition year of Chinese fir clones by chemical composition.

\section{Abbreviations}

JW: Juvenile wood; MW: Mature wood; EW: Early wood; LW: Late wood; TL: Tracheid length; MFA: Microfibril angle; TD: Tracheid diameter; DWT: Double cell wall thickness; LC: Lignin content; a-CC: a-Cellulose content; HC: Holocellulose content; EC: Extractive content.

\section{Acknowledgements}

We acknowledge Yunfei You and Yitang Cheng for providing trees. We are also grateful for technical assistance from Yinliang Yu, Mengyu Zhou, Shaoqing Wang, Shiliu Zhu.

\section{Authors' contributions}

Conceptualization: C.L., and S.L.; methodology: C.L.; software, C.L.; validation: C.L. and Y. Y.; formal analysis: C.L.; investigation: Q.J and S.L.; resources: C.L., Y.Y., Q. J. and S.L.; data curation: Y.L.; writing —original draft preparation: C.L.; writing - review and editing: C.L. Q.J. Y.L. and S.L.; supervision: S.L.; project administration: S.L.; funding acquisition: C.L. and S.L. All authors have read and approved the final manuscript.

\section{Funding}

This research was funded by the National Key Research and Development Program of China (No. 2017YFD0600201).

\section{Availability of data and materials}

Available upon reasonable request.

\section{Declarations}

\section{Competing interests}

The authors declare no conflict of interest.

\section{Author details}

'School of Forestry and Landscape Architecture, Key Lab of State Forest and Grassland Administration on "Wood Quality Improvement and High Efficient Utilization", Anhui Agricultural University, Hefei 230036, China. ${ }^{2}$ Bozhou University, 2266 Tangwang Avenue, Bozhou 236800, People's
Republic of China. ${ }^{3}$ Yangkou State Owned Forest Farm of Fujian Province, Nanping 353000, China.

Received: 19 August 2021 Accepted: 3 December 2021

Published online: 20 December 2021

\section{References}

1. Liu CLC, Kuchma O, Krutovsky KV (2018) Mixed-species versus monocultures in plantation forestry: development, benefits, ecosystem services and perspectives for the future. Glob Ecol Conserv 15:e0419. https://doi. org/10.1016/j.gecco.2018.e00419

2. Jürgensen C, Kollert W, Lebedys A (2014) Assessment of industrial roundwood production from planted forests. Planted Forests and Trees Working Papers (FAO) eng no FP/48/E

3. Wang Z, Ma L, Jia Z, Wei H, Duan J (2016) Interactive effects of irrigation and exponential fertilization on nutritional characteristics in Populus $x$ euramericana cv. ${ }^{\prime} 74 / 76$ ' cuttings in an open-air nursery in Beijing, China. J For Res 27(3):569-582

4. Kijidani Y, Tsuyama T, Takata K (2021) Seasonal variations of auxin and gibberellin A4 levels in cambial-region tissues of three conifers (Pinus elliottii, Chamaecyparis obtusa, and Cryptomeria japonica) with inherently different wood densities. J Wood Sci 67(1):46. https://doi.org/10.1186/ s10086-021-01977-5

5. Zhang X, Cao QV, Duan A, Zhang J (2016) Self-thinning trajectories of Chinese fir plantations in southern China. For Sci 62(6):594-599. https:// doi.org/10.5849/forsci.16-004

6. Huang ZQ, Wan XH, He ZM, Yu ZP, Wang H, Hu ZH, Yang YS (2013) Soil microbial biomass, community composition and soil nitrogen cycling in relation to tree species in subtropical China. Soil Biol Biochem 62:68-75. https://doi.org/10.1016/j.soilbio.2013.03.008

7. Wei XH, Blanco JA, Jiang H, Kimmins JPH (2012) Effects of nitrogen deposition on carbon sequestration in Chinese fir forest ecosystems. Sci Total Environ 416:351-361. https://doi.org/10.1016/j.scitotenv.2011.11.087

8. Lin E, Zhuang H, Yu J, Liu X, Huang H, Zhu M, Tong Z (2020) Genome survey of Chinese fir (Cunninghamia lanceolata): identification of genomic SSRs and demonstration of their utility in genetic diversity analysis. Sci Rep. https://doi.org/10.1038/S41598-020-61611-0

9. Wang Y, Jia R, Sun H, Liu Y, Lyu J, Zhao R, Liu S (2021) Wood mechanical properties and their correlation with microstructure in Chinese fir clones. IAWA J. https://doi.org/10.1163/22941932-bja10047

10. Bao FC, Jiang ZH, Jiang XM, Lu XX, Luo XQ, Zhang SY (2001) Differences in wood properties between juvenile wood and mature wood in 10 species grown in China. Wood Sci Technol 35(4):363-375. https://doi.org/10. 1007/s002260100099

11. Alteyrac J, Cloutier A, Zhang SY (2006) Characterization of juvenile wood to mature wood transition age in black spruce (Picea mariana (Mill.) B.S.P.) at different stand densities and sampling heights. Wood Sci Technol 40(2):124-138. https://doi.org/10.1007/s00226-005-0047-4

12. Cown D (1992) Corewood (juvenile wood) in Pinus radiate—should we be concerned? NZ J For Sci 22:87-95

13. Moore JR, Cown DJ (2017) Corewood (juvenile wood) and its impact on wood utilisation. Curr For Rep 3(2):107-118. https://doi.org/10.1007/ s40725-017-0055-2

14. Anoop EV, Rao RV, Mukundan G (2019) Wood anatomy and wood property variation in red sanders. In: Pullaiah T, Balasubramanya S, Anuradha M (eds) Red sanders: silviculture and conservation. Springer Singapore, Singapore, pp 131-152. https://doi.org/10.1007/978-981-13-7627-6_11

15. Palermo GPdM, Latorraca JVdF, Carvalho AMd, Calonego FW, Severo ETD (2015) Anatomical properties of Eucalyptus grandis wood and transition age between the juvenile and mature woods. Eur J Wood Wood Prod 73(6):775-780. https://doi.org/10.1007/S00107-015-0947-4

16. Wang YP, Zhang R, Zhou ZC (2021) Radial variation of wood anatomical properties determines the demarcation of juvenile-mature wood in Schima superba. Forests. https://doi.org/10.3390/f12040512

17. Richter C. (2015) The anatomical structure of wood. In: Wood characteristics. Springer, Cham. https://doi.org/10.1007/978-3-319-07422-1_1

18. Darmawan W, Nandika D, Rahayu I, Fournier M, Marchal R (2013) Determination of juvenile and mature transition ring for fast growing sengon 
and jabon wood. J Indian Acad Wood Sci. https://doi.org/10.1007/ s13196-013-0091-x

19. Zhang S, Belien E, Ren H, Rossi S, Huang JG (2020) Wood anatomy of boreal species in a warming world: a review. iForest Biogeosci For 13(2):130-138. https://doi.org/10.3832/ifor3230-013

20. Timell TE (1986) Compression wood in gymnosperms. Springer, Berlin

21. Zobel B (1981) Wood quality from fast-grown plantations. Tappi 64:71-74

22. Nawrot M, Pazdrowski W, Walkowiak R, Szymański M, Kaźmierczak K (2018) Analysis of coniferous species to identify and distinguish juvenile and mature wood. J For Sci 60(4):143-153. https://doi.org/10.17221/78/ 2013-JFS

23. Abdel-Gadir AY, Krahmer RL (1993) Estimating the age of demarcation of juvenile and mature wood in Douglas-fir. Wood Fiber Sci 25:242-249

24. Sauter UH, Mutz R, Munro BD (2007) Determining juvenile-mature wood transition in scots pine using latewood density. Wood Fiber Sci 31(4):416-425

25. Bhat KM, Priya PB, Rugmini P (2001) Characterisation of juvenile wood in teak. Wood Sci Technol 34(6):517-532. https://doi.org/10.1007/s0022 60000067

26. Mansfield SD, Parish R, Goudie JW, Kang KY, Ott P (2007) The effects of crown ratio on the transition from juvenile to mature wood production in lodgepole pine in western Canada. Can J For Res 37(8):1450-1459. https://doi.org/10.1139/x06-299

27. Mansfield SD, Parish R, Di Lucca CM, Goudie J, Kang KY, Ott P (2009) Revisiting the transition between juvenile and mature wood: a comparison of fibre length, microfibril angle and relative wood density in lodgepole pine. Holzforschung 63(4):449-456. https://doi.org/10.1515/hf.2009.069

28. Clark A, Daniels RF, Jordan L (2006) Juvenile/mature wood transition in loblolly pine as defined by annual ring specific gravity, proportion of latewood, and microfibril angle. Wood Fiber Sci 38(2):292-299

29. Zhu J, Tadooka N, Takata K, Koizumi A (2005) Growth and wood quality of sugi (Cryptomeria japonica) planted in Akita prefecture (II). Juvenile/ mature wood determination of aged trees. J Wood Sci 51(2):95-101. https://doi.org/10.1007/s10086-004-0623-5

30. Shupe T, Hse C-Y, Choong ET, Groom LH (1997) Differences in some chemical properties of innerwood and outerwood from five silviculturally different loblolly pine stands. Wood Fiber Sci 29:91-97

31. Funda T, Fundova I, Gorzsás A, Fries A, Wu HX (2020) Predicting the chemical composition of juvenile and mature woods in Scots pine (Pinus sylvestris L.) using FTIR spectroscopy. Wood Sci Technol 54(2):289-311. https://doi.org/10.1007/S00226-020-01159-4

32. Francisco-Fernández M, Tarrío-Saavedra J, Naya S, López-Beceiro J, Artiaga $R$ (2017) Statistical classification of early and late wood through the growth rings using thermogravimetric analysis. J Therm Anal Calorim 127(1):499-506. https://doi.org/10.1007/s10973-016-5917-5

33. GB/T10336-2002 Pulps - determination of fiber length by automated optical analysis Beijing: Standards Press of China. 2002.

34. GB/T 36055-2018 Method for analysis of forestry biomass — determination of moisture content Beijing: Standards Press of China. 2018.

35. GB/T 35816-2018 Standard method for analysis of forestry biomassdetermination of extractives content Beijing: Standards Press of China. 2018.

36. GB/T 35818-2018 Standard method for analysis of forestry biomassdetermination of structural polysaccharides and lignin Beijing: Standards Press of China. 2018.

37. GB/T744-2004 Pulps_-determination of alkali resistance Beijing: Standards Press of China. 2004.

38. Ferreira AL, Severo ETD, Calonego FW (2011) Determination of fiber length and juvenile and mature wood zones from Hevea brasiliensis trees grown in Brazil. Eur J Wood Wood Products 69(4):659-662. https://doi. org/10.1007/s00107-010-0510-2

39. Vega M, Hamilton M, Downes G, Harrison PA, Potts B (2020) Radial variation in modulus of elasticity, microfibril angle and wood density of veneer logs from plantation-grown Eucalyptus nitens. Ann For Sci 77(3):65. https://doi.org/10.1007/s13595-020-00961-1

40. Zhang Y, Song K, Tong D (2013) Prediction of mature wood anatomical properties of Pinus banksiana plantation based on support vector machines (SVM). Sci Silvae Sin 49(9):119-125

41. Jian L et al (1999) Demarcation of juvenile wood and mature wood of planted Chinese fir and its wood quality prediction. J Northeast For Univ 27(4):24-28
42. Adamopoulos S, Passialis C, Voulgaridis E (2007) Strength properties of juvenile and mature wood in black locust (Robinia pseudoacacia L.). Wood Fiber Sci 39(2):241-249

43. Csoka L, Zhu J, Takata K (2005) Application of the Fourier analysis to determine the demarcation between juvenile and mature wood. J Wood Sci 51(3):309-311. https://doi.org/10.1007/S10086-005-0722-Y

44. Butterfield B (2003) Wood anatomy in relation to wood quality. Wood Quality and Its Biological Basis, Orgs 30-52

45. Farber J, Lichtenegger HC, Reiterer A, Stanzl-Tschegg S, Fratzl P (2001) Cellulose microfibril angles in a spruce branch and mechanical implications. J Mater Sci 36(21):5087-5092. https://doi.org/10.1023/a:1012465005607

46. Wang HK, Yu ZX, Zhang XX, Ren D, Yu Y (2017) The combined effects of initial microfibrillar angle and moisture contents on the tensile mechanical properties and angle alteration of wood foils during tension. Holzforschung 71(6):491-497. https://doi.org/10.1515/hf-2016-0138

47. Xu P, Liu HW, Donaldson LA, Zhang Y (2011) Mechanical performance and cellulose microfibrils in wood with high S2 microfibril angles. J Mater Sci 46(2):534-540. https://doi.org/10.1007/s10853-010-5000-8

48. Donaldson L (2008) Microfibril angle: measurement, variation and relationships-a review. IAWA J 29(4):345-386. https://doi.org/10.1163/ 22941932-90000192

49. Krauss A (2010) Variation in the microfibril angle in tangential walls of pine wood tracheids (Pinus sylvestris L.). Wood Res 55(2):7-12

50. Wang M, Stewart JD (2012) Determining the transition from juvenile to mature wood microfibril angle in lodgepole pine: a comparison of six different two-segment models. Ann For Sci 69(8):927-937. https://doi.org/ 10.1007/s13595-012-0226-Z

51. Sheng J, Chen J, Liu C, Yang Z, Yang Y, Guan X, Lin J (2020) Changes in the chemical composition of young Chinese fir wood exposed to different soil temperature and water content. Cellulose 27(7):4067-4077. https:// doi.org/10.1007/s10570-020-03039-3

52. Liu Y, Zhou L, Guan Y, Hu J, Zhao Z, Gao H, Liu S (2021) Radial variations to wood anatomical and chemical properties in eight poplar clones. Can J For Res. https://doi.org/10.1139/cjfr-2020-0465

53. Celedon JM, Chiang A, Yuen MMS, Diaz-Chavez ML, Madilao LL, Finnegan PM, Barbour EL, Bohlmann J (2016) Heartwood-specific transcriptome and metabolite signatures of tropical sandalwood (Santalum album) reveal the final step of (Z)-santalol fragrance biosynthesis. Plant J 86(4):289-299. https://doi.org/10.1111/tpj.13162

54. Celedon JM, Bohlmann J (2018) An extended model of heartwood secondary metabolism informed by functional genomics. Tree Physiol 38(3):311-319. https://doi.org/10.1093/treephys/tpx070

55. Sunny P, Anoop E, Jesma A, Kattany V, Kunhamu TK, Santhooshkumar AV, Hrideek TK (2021) Correlation and regression studies on wood properties of jack (Artocarpus heterophyllus Lam.) for effective timber utilization. Int J Chem Stud 9(2):903-910. https://doi.org/10.22271/chemi.2021.v9.i2m. 11934

\section{Publisher's Note}

Springer Nature remains neutral with regard to jurisdictional claims in published maps and institutional affiliations.

\section{Submit your manuscript to a SpringerOpen ${ }^{\odot}$ journal and benefit from:}

- Convenient online submission

- Rigorous peer review

- Open access: articles freely available online

- High visibility within the field

- Retaining the copyright to your article

Submit your next manuscript at $\boldsymbol{\nabla}$ springeropen.com 